\title{
An Electron-microscopic Demonstration of an Acidic Polysaccharide Involved in the Adhesion of a Marine Bacterium to Solid Surfaces
}

\author{
By MADILYN FLETCHER AND G. D. FLOODGATE \\ Marine Science Laboratories, University College of North Wales, \\ Menai Bridge, Anglesey
}

(Received 26 May 1972; revised I I October 1972)

\begin{abstract}
SUMMARY
Staining a marine bacterium with Ruthenium Red and Alcian Blue demonstrated an extracellular, compact acidic polysaccharide layer, which was involved in bacterial adhesion to surfaces. The adhesive substance was present on suspended bacteria and appeared to assist adhesion when they were forced into contact with a suitable surface. Bacteria, which had attached to a surface naturally, produced a secondary fibrous acidic polysaccharide, which probably developed from the primary polysaccharide, and could eventually replace it.

A high $\mathrm{pH}$ in the growth medium almost totally prevented the appearance of primary polysaccharide in preparations of naturally attached bacteria, which were surrounded by the reticular secondary polysaccharide, and adhesion was not impaired. In contrast to naturally attached bacteria, those forcibly attached were surrounded by primary polysaccharide.

High temperature lowered the number of bacteria attached, relative to culture density, but did not affect the appearance of the adhesive substance.
\end{abstract}

\section{INTRODUCTION}

The adhesion of bacteria to solid surfaces is a phenomenon which occurs both in natural environments and under laboratory conditions, and the process is said to encourage growth of bacteria when the organic nutrient concentration is very low (ZoBell, r943). Various modes of attachment recently reviewed by Corpe (1970 $b$ ) and Floodgate (I972), include fimbriae or pili (Duguid, 1959; Brinton, 1967), stalks and holdfasts (Poindexter, 1964; Moll, Ahrens \& Rheinheimer, I967) and capsular polysaccharides (ZoBell, I943; Jones, Roth \& Sanders, I969; Corpe, (970a).

Bacterial attachment has been investigated from an ecological standpoint using the light microscope (Cholodny, 1930; Henrici, I933; Meyer, I935; ZoBell \& Allen, I935; Anderson \& Meadows, 1966; Floodgate, 1966), but no structural details were observed. Hirsch \& Pankratz (1970) submerged Formvar- or collodion-coated grids in an aquatic environment and metal-shadowed the film with its attached bacteria for viewing in the electron microscope. A variety of adhesive mechanisms were indicated, but it was not possible to examine the relationship between a bacterium and the attachment surface at the point of contact. Jones et al. (1969) observed 7- and 9-day-old bacterial slime layers by preparing vertical sections through the bacterial layer and the underlying substrate.

In the present work, bacteria were examined in the electron microscope during the early stages of attachment. Since polysaccharide material may be involved in adhesion, an attempt was made to stain acidic polysaccharides using Ruthenium Red and Alcian Blue, to investi- 
gate: (i) whether an acidic polysaccharide is responsible for the adhesion of a strain of marine bacterium, (ii) whether the adhesive substance is present on both suspended and attached bacteria, or is produced only after the organisms contact a suitable attachment surface, and (iii) whether the nature of the adhesive substance is affected by the peptone concentration, $\mathrm{pH}$ or temperature of the growth medium.

\section{METHODS}

Isolation of organism. Perspex slides were suspended just below the sea-water surface in the Menai Straits, Anglesey, for $5 \mathrm{~h}$ (in situ $\mathrm{pH} 8 \cdot \mathrm{I}$ ). The slides were rinsed in distilled water, inverted on agar plates and left overnight at $4{ }^{\circ} \mathrm{C}$. The slides were then removed, and the plates incubated at the same temperature. After a week, pure cultures were established from colonies on the plates by two consecutive transfers to agar plates, and maintained on agar slants at $4{ }^{\circ} \mathrm{C}$. The organism used for this investigation was an unidentified Gram-negative, motile rod.

The medium used for all stages of isolation was $0 . \mathrm{I} \%$ (w/v) peptone (Oxoid Ltd, London), $0.1 \%(\mathrm{w} / \mathrm{v})$ yeast extract (Oxoid Ltd) in aged sea-water, $\mathrm{pH} 7 \cdot 4$.

Preparation of cultures for electron microscopy. A standard inoculum for all experimental cultures was one loopful of a I-day culture grown at room temperature $\left(\mathrm{I} 6{ }^{\circ} \mathrm{C} \pm 4\right)$ in $70 \mathrm{ml}$ of the isolation medium except that $80 \%(\mathrm{v} / \mathrm{v})$ aged sea-water in distilled water was used. The same medium was used for Experimental Sets $\mathrm{I}-6$ excepting variations as follows:

Experimental Set $\mathrm{I}: \mathrm{I} \cdot 0 \%$ peptone; $2: 0 \cdot \mathrm{I} \%$ peptone; $3: 0.0 \mathrm{I} \%$ peptone, all at $\mathrm{I} 2$ to $\mathrm{I} 4{ }^{\circ} \mathrm{C}$, $\mathrm{pH} 7 \cdot 4$;

Experimental Set $4: \mathrm{pH} 8 \cdot 0 ; 5: \mathrm{pH} 8.6$; each at $0 . \mathrm{I} \%$ peptone, I 2 to $\mathrm{I} 4{ }^{\circ} \mathrm{C}$;

Experimental Set $6: 25^{\circ} \mathrm{C}$ at $0 \cdot 1 \%$ peptone, $\mathrm{pH} 7 \cdot 4$.

Samples of media $(250 \mathrm{ml})$ were inoculated and incubated at the appropriate temperature with aeration by bubbling for $22 \mathrm{~h}$, allowing bacterial attachment during the lag and exponential growth phases. Each experiment was prepared in triplicate.

Each culture flask contained 2-cm sq. pieces of MF-Millipore filter [Millipore (U.K.) Ltd, London] to provide a surface for attachment. Millipore filters were chosen since bacteria adhere to them readily, they are easily manipulated during fixation, embedding and sectioning, and they are readily distinguished in the electron microscope. The filter is biologically inert and does not react ionically in the medium used (Millipore, 1966). A pore size of $0.22 \mu \mathrm{m}$ was employed to prevent penetration of the filter by the bacteria. At the end of the incubation period the filters within the culture were removed, cut into pieces with a razor blade, fixed and embedded (see below).

For comparison with attached bacteria, samples of suspended organisms were obtained for fixation by taking a $\mathrm{I}-\mathrm{ml}$ sample from the culture and mixing it with $2 \mathrm{ml}$ of $3.6 \%$ glutaraldehyde (TAAB, Reading, Berkshire) in distilled water. Approximately I ml of the resulting suspension was passed through a Millipore filter, and the filter with the adhering bacteria was fixed and embedded (see below). For Experimental Set 5, approximately twice these quantities were used since the bacterial concentration was very low.

Electron microscopy. The following fixation methods were used to stain acidic polysaccharide for the electron microscope: (i) Ruthenium Red (TAAB). The procedure was that used by Pate \& Ordal (1967) and is thought to specifically stain acidic polysaccharide. Controls were prepared by substituting distilled water for Ruthenium Red stock solution in the procedure; (ii) Alcian Blue (Raymond A. Lamb, Alperton, Middlesex). The procedure (Behnke, I 968) included fixation of the filters with glutaraldehyde for $\mathrm{I}_{5} 5 \mathrm{~h}$ and with $\mathrm{OsO}_{4}$ (British 
Drug Houses Ltd, Poole, Dorset) for $2 \mathrm{~h}$. Controls were prepared by omitting Alcian Blue from the glutaraldehyde fixative.

All filters were dehydrated in alcohol and embedded in Araldite. Sections were cut on an LKB ultramicrotome using glass knives, stained with lead citrate (Reynolds, 1963) and examined in an AEI EM6B electron microscope operating at $60 \mathrm{kV}$.

\section{RESULTS}

The quality of fixation and the localization of acidic polysaccharide in Ruthenium Red-and Alcian Blue-treated bacteria. Naturally attached and suspended, i.e. forcibly attached, bacteria were examined for the presence of acidic polysaccharide, as indicated by Ruthenium Red (RR) and Alcian Blue (AB) staining. The naturally attached bacteria examined comprising (i) those adhering to the surface from the medium and (ii) those resulting from replication on the surface could not be distinguished unless a bacterium was actually seen to be dividing. However, several dividing bacteria were usually observed in microcolonies, and probably many within a colony originated from replication on the surface.

With RR fixation there was good preservation of morphology and excellent contrast of structures (Fig. I, 2, 3). The bacterial wall was the multilayered structure typical of Gramnegative bacteria (Salton, I964). With AB treatment, there was poorer contrast and the layered structure of the wall could not be distinguished (Fig. 4). Alcian Blue 8GX has commonly been used in light microscopy as a stain specific for acidic polysaccharides at low $\mathrm{pH}$ for a short staining time. However, the $\mathrm{pH}$ of the $\mathrm{AB} /$ glutaraldehyde fixative used in this investigation $(6.5)$ was too high to stain polysaccharides specifically and the method merely corroborated the presence of an acidic substance exterior to the bacterial wall indicated by RR staining. Since both RR and AB demonstrated an acidic material exterior to the wall, the polysaccharide probably surrounds the wall in situ and is not leached from it during fixation.

In RR preparations, two types of acidic material were evident which were not visible in unstained preparations. The first substance, designated primary acidic polysaccharide, was an electron-dense layer ( $P$ in Fig. I) on the wall surface of both suspended and attached bacteria. This substance was almost absent from microcolonies or preparations of attached bacteria grown at a high $\mathrm{pH}$. The primary polysaccharide layer can be further differentiated into two regions: (i) an inner thin, dense line (L in Fig. I) on the wall surface, and (ii) an outer, fine-grained 'fringe' region ( $F$ in Fig. I) about 15 to $25 \mathrm{~nm}$ thick. Alcian Blue-treated bacteria demonstrated a region of amorphous, electron-dense material exterior to the wall (P in Fig. 4) which is probably the primary acidic polysaccharide.

The primary acidic polysaccharide is probably initially responsible for bacterial adhesion. When suspended organisms were forced into contact with a filter surface, the portion of the primary polysaccharide coat adjacent to the filter surface appeared to 'stretch' and bridge the gap between the bacterial and filter surfaces (Fig. 6). This same appearance was noted with the primary polysaccharide of single naturally attached bacteria (Fig. I), which suggests that the initial stage of attachment in both naturally and forcibly attached bacteria involves adhesion of the organism to the surface by means of the coat of primary polysaccharide.

Secondary acidic polysaccharide was found predominantly in preparations of attached bacteria and was usually associated with groups of organisms (Fig. 2, 3). It was a fibrous, reticular substance which stretched between and around adjacent bacteria or between bacteria and the filter surface. In AB preparations, where secondary acidic polysaccharide was expected to occur, e.g. in microcolonies, the $\mathrm{AB}$ appeared to have coagulated the acidic 


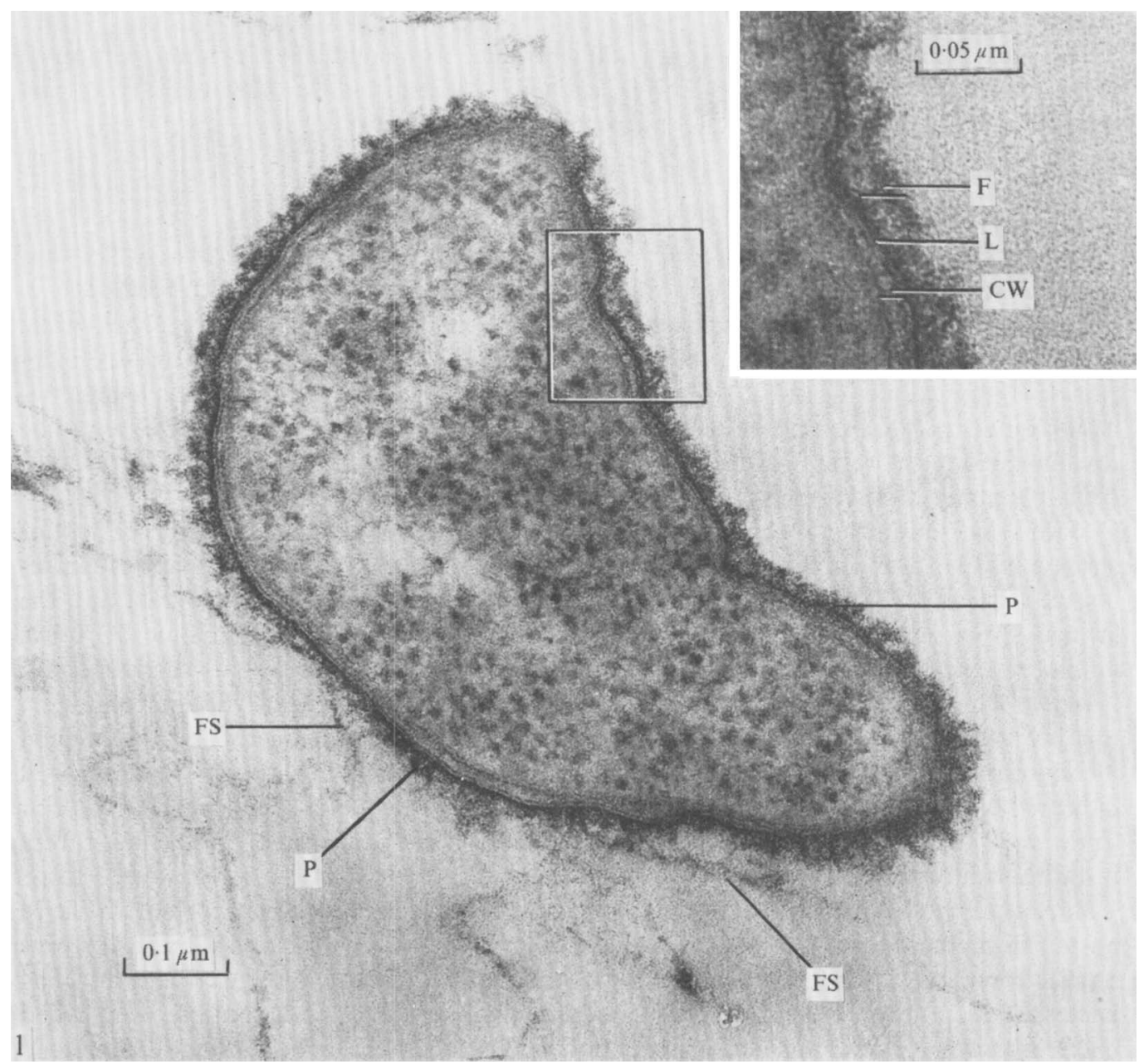

Fig. I. A naturally attached bacterium from Experimental Set 2 treated with RR. The multilayered wall $(\mathrm{CW})$ is surrounded by primary acidic polysaccharide $(\mathrm{P})$ which appears to attach the bacterium to the filter surface (FS). Primary polysaccharide can be differentiated into a thin, dense line on the wall surface $(L)$ and an outer 'fringe' region $(F)$.

material on to the bacterial surfaces and in dense strands between them (Fig. 5), making distinction between primary and secondary polysaccharides difficult.

The secondary acidic polysaccharide probably evolved from the primary polysaccharide after attachment. The primary polysaccharide became stretched and fibrous in areas where bacteria were adjacent to each other or the filter surface, and assumed the appearance of secondary acidic polysaccharide ( $\mathrm{S}$ in Fig. 7). In microcolonies, however, the secondary polysaccharide completely replaced the primary polysaccharide (Fig. 2, 3), indicating that the production of secondary polysaccharide is a time-dependent process. The thin, electrondense line (L in Fig. I, 3) is usually present on the bacterial surface, irrespective of the type of polysaccharide surrounding it, and this may indicate that it is the area of synthesis.

RR staining of microcolonies was most dense at the colony surface (Fig. 3). This could be 

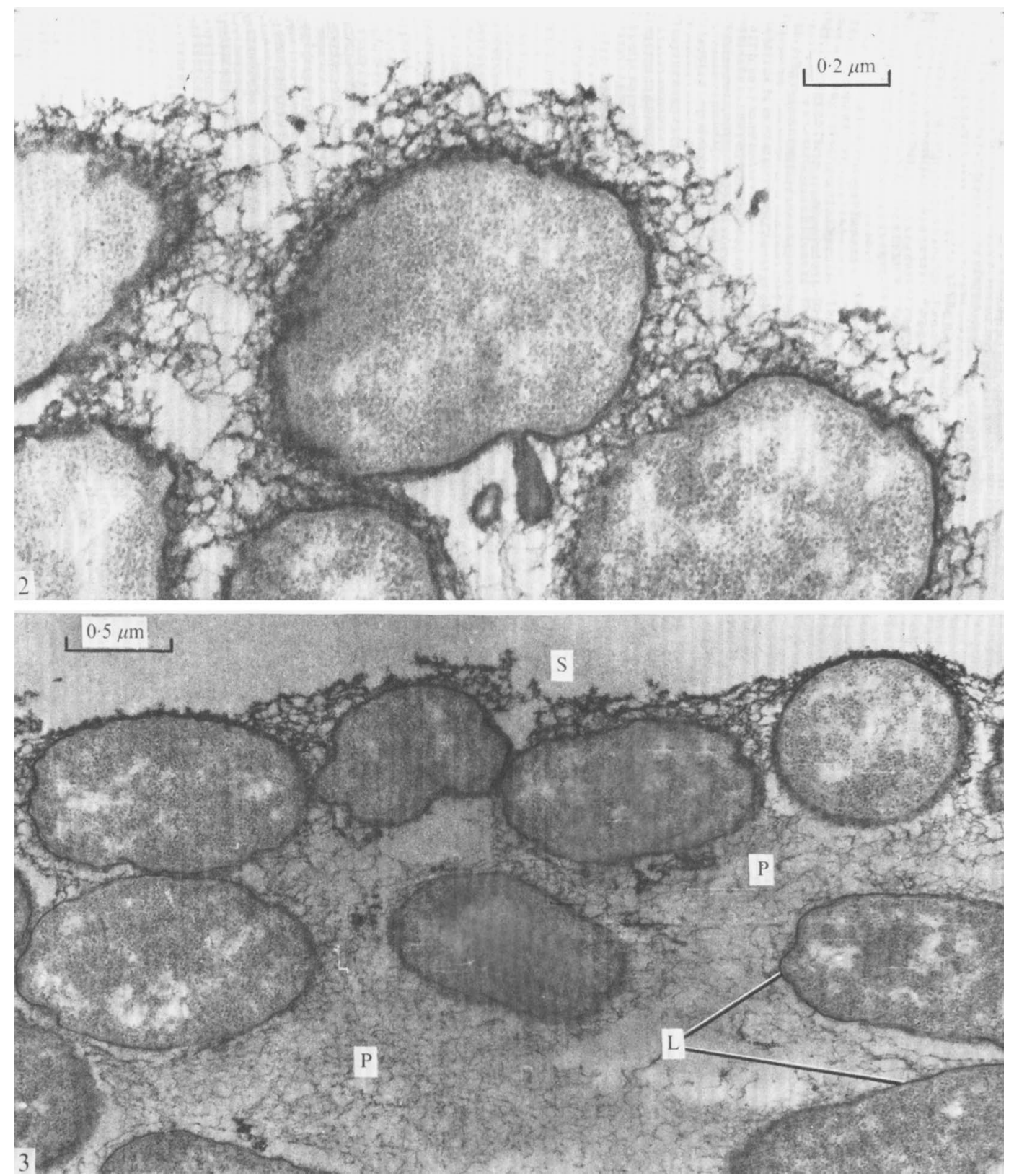

Fig. 2. A group of naturally attached bacteria from Experimental Set I treated with RR. Secondary acidic polysaccharide stretches around and between the organisms.

Fig. 3. A portion of a microcolony from Experimental Set I treated with RR. The bacteria are located in a mat of secondary acidic polysaccharide (P) and RR-staining is most dense at the colony surface (S). A dense line (L) can be observed on wall surfaces when they are cut in cross-section. 

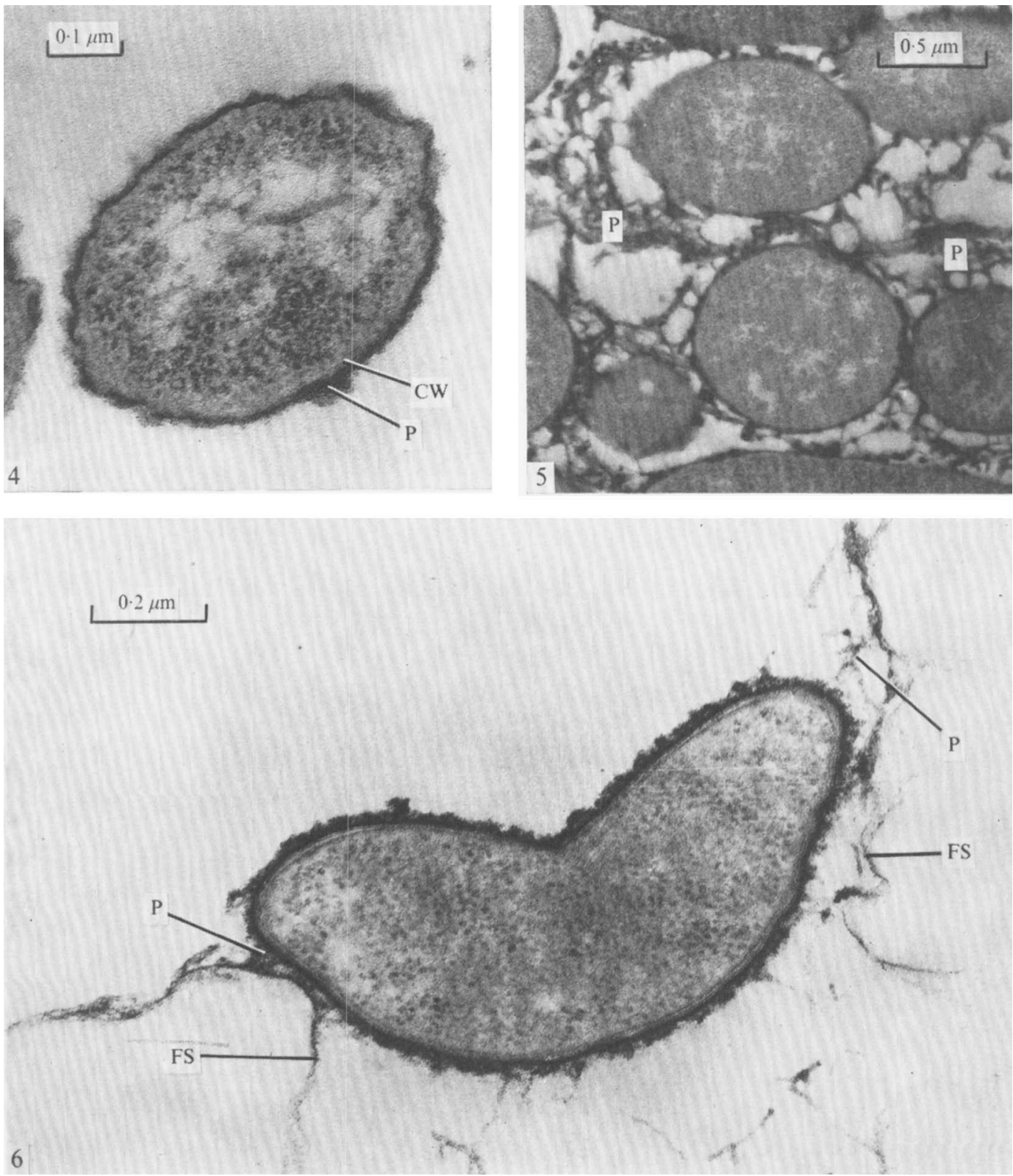

Fig. 4. A suspended, i.e. forcibly attached, bacterium from Experimental Set 3 treated with AB. Dense amorphous material (P) (probably primary acidic polysaccharide) surrounds the wall (CW).

Fig. 5. A portion of a microcolony from Experimental Set I treated with AB. The acidic material (P) appears to have coagulated down on to the bacterial surfaces and into dense strands between the organisms.

Fig. 6. A forcibly attached bacterium from Experimental Set 4 treated with RR. Primary polysaccharide (P) becomes stretched and fibrous in the area of contact with the filter surface (FS) and appears to bridge the gap between the two surfaces. 
the result of a concentration at the surface of acidic groups or a tendency of the polysaccharide to be impervious to the RR molecule.

The effects of peptone concentration, $\mathrm{pH}$ and temperature. The mean bacterial density $(\mathrm{mg} / \mathrm{ml})$ for each Experimental Set is as follows: Set $1: 0 \cdot 30$; Set 2:0.16; Set 3:0.17; Set 4: 0.18 ; Set 5:0.05; and Set 6:0.47.

A general assessment of the number of attached bacteria per unit area could be made by noting the frequency with which they occurred along the filter surface; distribution of bacteria was fairly consistent within each experiment, and differences in distribution between experiments were usually pronounced. The appearance of AB-treated bacteria correlated with that of RR-treated organisms.

Peptone concentration did not noticeably affect the number of bacteria attached proportional to culture concentration nor the nature of the polysaccharide; however, the levels of peptone concentration used were above the natural organic nutrient concentrations in seawater (usually less than $5 \mathrm{mg} / \mathrm{l}$, Krogh, 193I).

In cultures grown at $\mathrm{pH} 8 \cdot 6$, the number of bacteria attached, proportional to culture density, did not appear to be affected. Primary polysaccharide was almost totally absent from preparations of naturally attached organisms, and even isolated bacteria were surrounded by the reticular secondary material (P in Fig. 8). Suspended organisms (Fig. 9) grown at $\mathrm{pH} 8.6$ were surrounded by primary polysaccharide, suggesting that secondary polysaccharide formation in naturally attached populations occurred at the time of attachment, or very shortly thereafter. It is not clear whether formation of reticular material is a response of the organism to attachment or merely a structural change in the polysaccharide at the filter surface.

Except at $25^{\circ} \mathrm{C}$, the number of attached bacteria was generally proportional to the density of suspended bacteria. At $25^{\circ} \mathrm{C}$, despite a high culture density, few bacteria were attached to the filter surface. No explanation for this discrepancy is demonstrated; the primary polysaccharide does not differ significantly in appearance from that in cultures grown at $\mathrm{I} 2$ to $14{ }^{\circ} \mathrm{C}$ (Fig. 10). However, a change in chemical characteristics might not be visible. Secondary polysaccharide was absent, but until its function has been demonstrated, it will not be known if the low frequency of attachment resulted from a possible inability to produce secondary polysaccharide.

\section{DISCUSSION}

Ruthenium Red has been widely used in electron microscopy to locate acidic polysaccharide-like material. Pate \& Ordal (1967) used RR in the fixation of Chondrococcus columnaris and found electron-dense material coating the surface of the outer wall which was thought to be an acidic polysaccharide and possibly involved in the adhesion of the organisms. Jones et al. (1969) used RR in the investigation of a bacterial slime layer from a simulated stream and found a polysaccharide-like mat, similar to secondary polysaccharide, within which the bacteria were located. Alcian Blue was used as a means of improving fixation of, or producing electron density in, acidic polysaccharides (Tice \& Barrnett, I965; Behnke, ı968; Zelander \& Behnke, 1970).

Additional evidence exists for an outer bacterial wall layer, invisible by conventional electron-microscopical fixation and staining techniques and occupying the region of primary polysaccharide. Bolle \& Kellenberger (1959) revealed an external layer, about $15 \mathrm{~nm}$ thick, by coating sections of walls with antiserum. Forsberg, Costerton \& MacLeod (I970) demonstrated the presence of a loosely bound outer wall layer on a marine pseudomonad by successive separation and analysis of wall layers. 

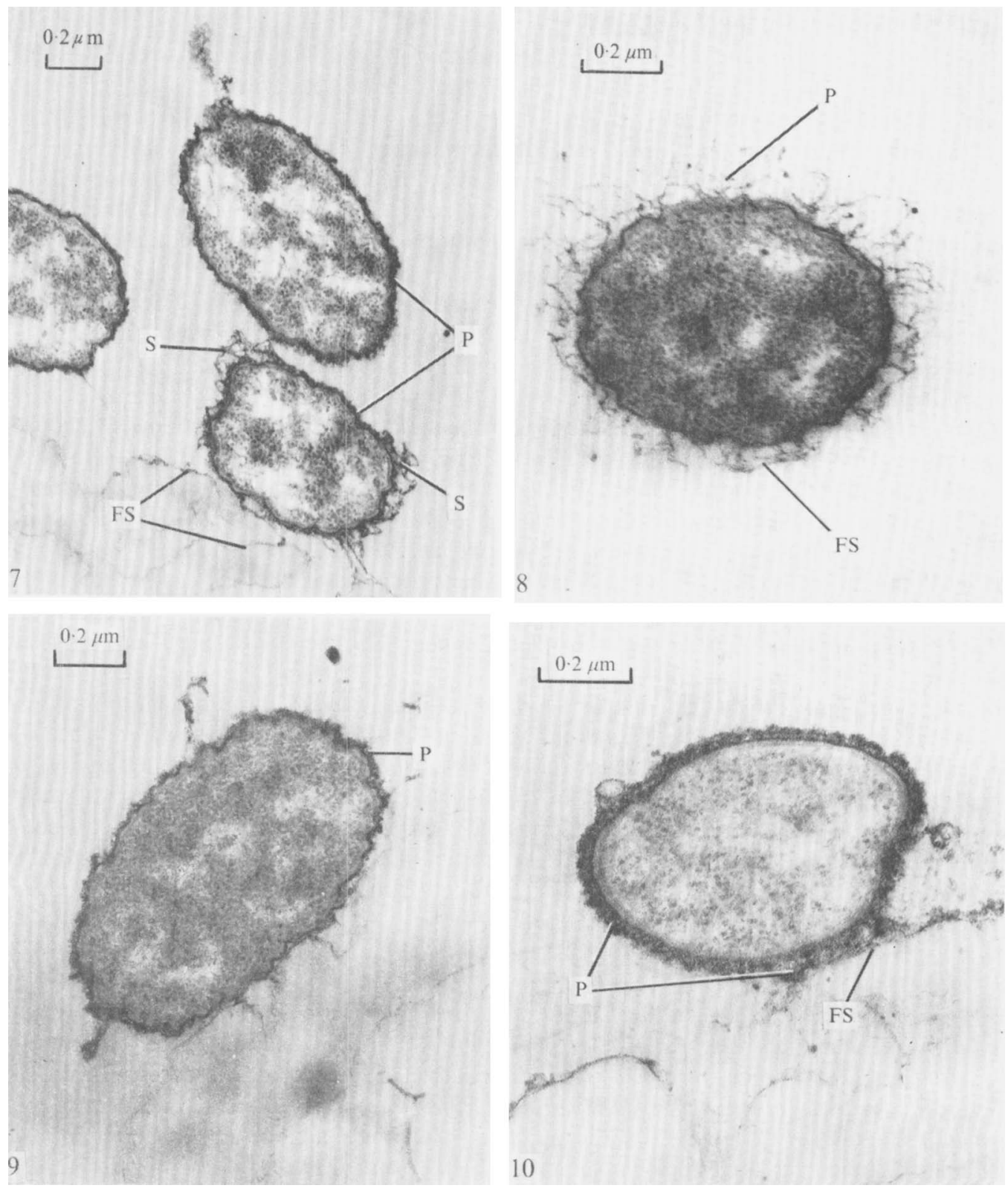

Fig. 7. A group of naturally attached bacteria from Experimental Set 2 treated with RR. Secondary acidic polysaccharide (S) appears to evolve from primary acidic polysaccharide $(\mathrm{P})$ in some areas. FS, filter surface.

Fig. 8. A naturally attached bacterium from Experimental Set 5 treated with RR, demonstrating reticular appearance of the surrounding polysaccharide (P). FS, filter surface.

Fig. 9. A suspended bacterium from Experimental Set 5 treated with RR, showing compact primary polysaccharide (P).

Fig. Io. A naturally attached bacterium from Experimental Set 6 treated with RR. The primary polysaccharide $(\mathrm{P})$ surrounding the organism resembles that found in Experimental Sets I-4. FS, filter surface. 
Marshall, Stout \& Mitchell (197I) found a fibrous polymer associated with the attachment of a Pseudomonas sp. and thought that such a material was probably necessary for firm bacterial adhesion. According to these workers, there were two phases of bacterial sorption: (i) a reversible phase, during which the bacterium was weakly held at the surface by a balancing of the London-van der Waals attractive forces and the electrical repulsive energies of the two surfaces, followed by (ii) a time-dependent irreversible phase, in which the bacterium was firmly attached to the surface. They believed that during the reversible phase of sorption, actual contact between the bacterium and settlement substrate surfaces was prevented by the electrical repulsive energies of the two surfaces, and that these repulsive forces were overcome during irreversible sorption by polymeric bridging.

The results of this investigation support the foregoing suggestion, as a fibrous polymer, i.e. secondary acidic polysaccharide, appeared to be involved in irreversible sorption. However, secondary polysaccharide was not necessary for irreversible adhesion; the initial stage of irreversible sorption occurred before the production of the fibrous secondary polysaccharide and involved contact between the settlement surface and the compact primary polysaccharide surrounding suspended bacteria.

The $\mathrm{pH}$ (Busch \& Stumm, I968) and electrolyte concentration (Marshall et al. I97I), of the medium can affect bacterial adhesion, as was suggested in the present work, and increase in temperature can alter the quantity or characteristics of the adhesive polysaccharide produced. The optimum temperature for carbohydrate production is not always so great as that for growth (Farrell \& Rose, 1967; Busch \& Stumm, I968; Brown \& Rose, 1969), and the strength of an adhesive polymer can decrease with an increase in temperature (Stanley \& Rose, I967).

This investigation was supported by the Natural Environment Research Council. The authors wish to thank Dr J. A. Nott and Dr K. P. Pugh for their very helpful advice and Mr D. C. Williams for the photographic work.

\section{REFERENCES}

Anderson, J. G. \& Meadows, P. S. (1966). Microorganisms attached to marine and fresh water sand grains. Nature, London 212, 1059-1060.

BEHNKE, O. (1968). Electron microscopical observations on the surface coating of human blood platelets. Journal of Ultrastructure Research 24, 5I-69.

Bolle, A. \& Kellenberger, E. (1959). Unpublished results in Kellenberger, E. \& Ryter, A. (1964). In bacteriology. In Modern Developments in Electron Microscopy. Edited by B. M. Siegel. London and New York: Academic Press.

BRINTON, C. C. (1967). Contributions of pili to the specificity of the bacterial surface, and unitary hypothesis of conjugal infectious heredity. In The Specificity of Cell Surfaces. Edited by B. D. Davis and L. Warren. Englewood Cliffs, New Jersey: Prentice-Hall.

Brown, C. M. \& Rose, A. H. (1969). Effects of temperature on composition and cell volume of Candida utilis. Journal of Bacteriology 97, 261-272.

Busch, P. L. \& Stumm, W. (I968). Chemical interactions in the aggregation of bacteria: bioflocculation in waste treatment. Environmental Science and Technology 2, 49-53.

Cholodny, N. (1930). Über eine neue Methode zur Untersuchung der Bodenmikroflora. Archiv für Mikrobiologie I, 620-652.

CORPE, W. A. (1970a). An acid polysaccharide produced by a primary film-forming marine bacterium. Developments in Industrial Microbiology II, 402-41 2.

Corpe, W. A. ( 1970 b). Attachment of marine bacteria to solid surfaces. In Adhesion in Biological Systems. Edited by R. S. Manly. New York and London: Academic Press.

Duguid, J.P. (I959). Fimbriae and adhesive properties in Klebsiella strains. Journal of General Microbiology 2I, 27 I-286. 
Farrell, J. \& Rose, A. H. (I967). Temperature effects on microorganisms. In Thermobiology. Edited by A. H. Rose. London and New York: Academic Press.

Floodgate, G. D. (1966). Factors affecting the settlement of a marine bacterium. Veröffentlichungen des Instituts für Meeresforschung in Bremerhaven 2, 265-270.

Floodgate, G. D. (I972). The mechanisms of bacterial attachment to detritus in aquatic systems. Memorie dell'Istituto Italiano di Idrobiologia (in the press).

Forsberg, C. W., Costerton, J. W. \& Macleod, R. A. (1970). Separation and localization of the cell wall layers of a gram-negative bacterium. Journal of Bacteriology ro4, I338-I 353.

Henrici, A. T. (I933). Studies of fresh water bacteria. I. A direct microscopic technique. Journal of Bacterio$\log y 25,277^{-2} 288$.

Hirsch, P. \& Pankratz, St H. (I970). Study of bacterial populations in natural environments by use of submerged electron microscope grids. Zeitschrift für Allgemeine Mikrobiologie ro, 589-605.

Jones, H. C., Roth, I. L. \& SAnders, W. M. (1969). Electron microscopic study of a slime layer. Journal of Bacteriology 99, 316-325.

Krogh, A. (I93I). Dissolved substances as food of aquatic organisms. Rapport et Procès-Verbaux des Réunions 75, 7-36.

Marshall, K. C., Stout, R. \& Mitchell, R. (197I). Mechanism of the initial events in the sorption of marine bacteria to surfaces. Journal of General Microbiology 68, 337-348.

Meyer, R. (1935). Zur Bestimmung der Mikroorganismen auf den Cholodnyschen Bodenplatten. Archiv für Mikrobiologie 6, 46I-470.

Millipore Catalogue MF-67 (1966). London: Millipore Corporation.

Moll, G., Ahrens, R. \& Rheinheimer, G. (1967). Elektronenoptische Untersuchungen über sternbildende Bakterien aus der Ostsee. Kieler Meeresforschungen 23, I37-147.

Pate, J. L. \& ORdal, E. J. (I967). The fine structure of Chondrococcus columnaris: III. The surface layers of Chondrococcus columnaris. Journal of Cell Biology 35, 37-5I.

Poindexter, J. S. (1964). Biological properties and classification of the Caulobacter group. Bacteriological Reviews 28, $231-295$.

REynolds, E. S. (1963). The use of lead citrate at high pH as an electron-opaque stain in electron microscopy. Journal of Cell Biology 17, 208-2 I 2.

Salton, M. R. J. (1964). The Bacterial Cell Wall. Amsterdam: Elsevier.

Stanley, S. O. \& Rose, A. H. (1967). On the clumping of Corynebacterium xerosis as affected by temperature. Journal of General Microbiology 48, 9-23.

Tice, L. W. \& BarrnetT, R. J. (1965). Diazophthalocyanins as reagents for fine structural cytochemistry. Journal of Cell Biology 25, 23-4I.

Zelander, T. \& BehnKe, O. (1970). Preservation of intercellular substances by the cationic dye Alcian Blue in preparative procedures for electron microscopy. Journal of Ultrastructure Research, 3I, 424-438.

ZoBELL, C. E. (1943). The effect of solid surfaces upon bacterial activity. Journal of Bacteriology 46, 39-56.

ZoBell, C. E. \& Allen, E. C. (1935). The significance of marine bacteria in the fouling of submerged surfaces. Journal of Bacteriology 29, 239-25I. 